\title{
Analisis Pendekatan Pembelajaran Contextual Teaching and Learning (CTL) terhadap Peningkatan Hasil Belajar Fisika dengan Metoda Library Research
}

\section{Liestiani Dewi*, Dwikoranto}

Program Studi Pendidikan Fisika, Jurusan Fisika, FMIPA, Universitas Negeri Surabaya

*Email: liestiani.17030184024@mhs.unesa.ac.id

DOI: https://doi.org/10.33369/pendipa.5.2.237-243

\begin{abstract}
This study aims to analyze the contextual teaching and learning $(C T L)$ approach to improv physics learning outcomes. This research used literature review and library research. The relevant method by combining relevant data according to what is being studied. The steps taken are reading, studying and reviewing literature related to the Contextual Teaching and Learning (CTL) learning approach and increasing learning outcomes. The data in this study are secondary data obtained from journals, articles, theses or other relevant sources. The data analysis technique used is descriptive analysis, gain test, normality test and paired sample t-test. The average result obtained during the pre-test is 37 . While the average result of the post-test is 83 and the average normalized acquisition test is 0.73. So that it is found that the $t_{\text {count }}$ is greater than the table value, it can be concluded that by applying the Contextual Teaching and Learning (CTL) learning approach there is an increase in student learning outcomes in physics learning, the application of the conventional learning approach.
\end{abstract}

Keywords: CTL, Library research, Learning outcomes.

\begin{abstract}
ABSTRAK
Penelitian ini bertujuan untuk menganalisis pendekatan pembelajaran Contextual Teaching and Learning (CTL) terhadap peningkatan hasil belajar fisika. Penelitian ini menggunakan penelitian kepustakaan (library research). Metode pengumpulan data dengan menggabungkan data yang relevan sesuai dengan yang sedang diteliti. Langkah yang dilakukan yaitu dengan membaca, mempelajari dan menelaah literatur yang berkaitan dengan pendekatan pembelajaran Contextual Teaching and Learning (CTL) dan peningkatan hasil belajar. Data dalam penelitian ini yaitu data sekunder yang diperoleh dari jurnal, artikel, skripsi maupun sumber-sumber lain yang relevan. Teknik analisis data yang digunakan yaitu analisis deskriptif, uji gain, uji normalitas dan uji-t sampel berpasangan. Hasil rata-rata yang didapatkan saat pretest yaitu sebesar 37. Sedangkan hasil rata-rata yang diperoleh post-test sebesar 83 dan rata-rata uji gain ternormalisasi sebesar 0,73. Sehingga didapat bahwa $t_{\text {hitung }}$ lebih besar dari nilai $t_{\text {tabel }}$ maka dapat disimpulkan bahwa dengan menerapkan pendekatan pembelajaran Contextual Teaching and Learning (CTL) terjadi peningkatan hasil belajar peserta didik pada pembelajaran fisika, daripada diterapkannya pendekatan pembelajaran konvensional.
\end{abstract}

Kata kunci: CTL, Library research, Hasil belajar.

\section{PENDAHULUAN}

Pendidikan adalah proses dimana seseorang individu mendapatkan bimbingan atau pengalaman sehingga dapat terus tumbuh menjadi manusia yang bebas, bertanggung jawab, inovatif dan berbudi luhur (Suyadi, 2013)

Ilmu Fisika merupakan ilmu yang mempelajari tentang sifat serta fenomena dan interaksi yang ada di alam. Alam dan gejalanya adalah sesuatu yang berhubungan dengan masalah di ilmu fisika. Sasaran telaah ilmu fisika yang terjadi karena berbagai hal yang dianggap rumit dan memiliki keterhubungan sehingga memunculkan suatu fakta, teori, prinsip, konsep dan hukum fisika. Hal-hal yang dianggap rumit tersebut dapat diatasi dengan konsep dasar ilmu 
fisika. Konsep tersebut dijadikan pedoman yang dapat membimbing ide sesorang (Arends, 2012).

Berdasarkan hasil wawancara dengan peserta didik saat melakukan Pengenalan Lapangan Persekolahan (PLP) di SMAN 1 Driyorejo diketahui bahwa fisika merupakan pelajaran yang sulit, banyak peserta didik yang hanya mampu menjawab soal yang sesui dengan contoh yang diberikan tetapi saat soal dimodifikasi peserta didik tidak bisa menjawabnya dengan tepat. Hal ini disebabkan oleh beberapa faktor salah satunya peserta didik kurang berlatih banyak soal atau pendekatan pembelajaran yang digunakan kurang inovatif.

Menurut Thobroni dan Arif (2013:24), hasil belajar merupakan transisi tingkah laku dengan totalitas tidak dengan aspek kemanusiaan saja yaitu hasil belajar yang dikelompokkan oleh pakar pendidikan yang tidak dilihat secara fragmentaris tetapi secara komprehensif. Hasil belajar adalah perkembangan yang mencerminkan keberhasilan peserta didik setelah mendapatkan pengalaman belajar. Hasil belajar peserta didik terdiri dari tiga aspek yaitu aspek kognitif, aspek afektif dan aspek psikomotor. Dengan melakukan suatu tes merupakan cara untuk menguji pemahaman peserta didik (Femi O., 2011).

Untuk mencapai sasaran pembelajaran yang ada maka guru harus membuat susunan aktivitas yang akan dilakukan mulai dari persiapan, menetapkan rencana, penentuan materi, metode pembelajaran dan evaluasi. Susunan aktivitas tersebut merupakan pendekatan pembelajaran.

Pendekatan pembelajaran Contextual Teaching and Learning (CTL) merupakan pendekatan yang berpusat pada peserta didik dengan mengutamakan keterhubungan materi pembelajaran di kehidupan nyata lalu mengaplikasikannya di kehidupan sehari-hari (Sagala S. , 2005).

Karena fisika adalah ilmu yang berkaitan dengan alam maka pendekatan pembelajaran CTL cocok diterapkan di pembelajaran fisika. Sehingga peserta didik mudah memahaminya serta menerapkannya di kehidupan sehari-hari. Penelitian ini bertujuan untuk menganalisis pendekatan pembelajaran Contextual Teaching and Learning (CTL) terhadap peningkatan hasil belajar fisika.

\section{METODA PENELITIAN}

Penelitian ini menggunakan penelitian kepustakaan (library research). Metode pengumpulan data dengan menggabungkan data yang relevan sesuai dengan yang sedang diteliti. Langkah yang dilakukan yaitu dengan membaca, mempelajari dan menelaah literatur yang berkaitan dengan pendekatan pembelajaran CTL dan peningkatan hasil belajar. Data dalam penelitian ini yaitu data sekunder yang diperoleh dari jurnal, artikel, skripsi maupun sumbersumber lain yang relevan. Teknik analisis data yang digunakan yaitu analisis deskriptif, uji gain, uji normalitas dan uji-t sampel berpasangan.

\section{HASIL DAN PEMBAHASAN}

Proses pembelajaran adalah hal yang sangat penting untuk membangun pemahaman peserta didik. Proses tersebut bukan hanya sebatas menghafal suatu konsep tetapi juga harus menghubungkan konsep yang telah dipelajari dengan kehidupan sehari-hari. Sehingga saat guru memberikan permasalahan ke peserta didik maka peserta didik mendapatkan penyelesaiannya sendiri, sehingga peserta didik ikut berperan aktif dalam pembelajaran.

Tabel 1. Data Hasil Pre-test, Post-test serta Gain peserta didik

\begin{tabular}{llll}
\hline $\begin{array}{l}\text { Yang } \\
\text { Ditentukan }\end{array}$ & Pre-test & Post-test & Gain \\
\hline Nilai Terendah & 13 & 67 & 0,38 \\
\hline Nilai Tertinggi & 67 & 100 & 1 \\
\hline Standar Deviasi & 13,402 & 8,957 & 0,134 \\
\hline Nilai Rata-Rata & 37 & 83 & 0,73 \\
\hline
\end{tabular}

(Neftyan, Suyanto, \& Suyatna, 2018)

Berdasarkan data penelitian yang diperoleh (Neftyan, Suyanto, \& Suyatna, 2018) didapatkan hasil bahwa hasil belajar signifikan pada 95\% itu dibuktikan dengan perbedaan pretest dan post-test yang dilakukan. Pendekatan CTL memiliki pengaruh sangat baik untuk 
kemajuan hasil belajar peserta didik itu dibuktikan dengan terjadinya peningkatan hasil belajar dan nilai N-Gain yang tinggi. Dapat ditunjukkan dengan tabel 1 .



Gambar 1. Grafik Perbedaan Rata-Rata Hasil Pre-test dan Post-test Peserta Didik (Neftyan, Suyanto, \& Suyatna, 2018)

Setelah melihat grafik yang menunjukkan hasil perbedaan rata-rata hasil pretest dan post-test yang dilakukan oleh peserta didik maka untuk mendapatkan sampel penelitian yang normal atau tidak normal akan dilakukannya uji normalitas. Ditunjukkan tabel 2 dimana uji normalitas menunjukkan nilai $\mathrm{p}>0,05$ sehingga sampel yang digunakan normal. langkah selanjutnya yaitu melakukan uji-t sampel berpasangan.
Tabel 2. Data Uji Normalitas Nilai Pre-test dan Post-test

\begin{tabular}{lll}
\hline Nilai dari & $\mathbf{p}$ & Kesimpulan \\
\hline Pre-test & 0,089 & H0 diterima \\
\hline Post-test & 0,053 & H0 diterima \\
\hline \multicolumn{2}{c}{ (Neftyan, Suyanto, \& Suyatna, 2018) }
\end{tabular}

Dilakukan uji-t sampel berpasangan untuk melihat ada tidaknya selisih hasil rata-rata kelas yang dibuat sampel menggunakan syarat data distribusi normal. Berdasarkan tabel 3 didapatkan hasil bahwa nilai p diperoleh $0,000<$ 0,050 maka $\mathrm{H}_{0}$ ditolak karena terdapat perbedaan hasil dari pre-test maupun post-test yang telah dilakukan oleh peserta didik. Perbedaan Hasil Pre-test dan Post-test yang dilaksanakan oleh peserta didik membuktikan terdapat pengaruh pendekatan CTL berkenaan dengan hasil belajar peserta didik.

Tabel 3. Hasil Uji-t Sampel Berpasangan

\begin{tabular}{llllll}
\hline Rata-Rata & Standar Deviasi & t & df & P & Kesimpulan \\
\hline$-45,844$ & 11,06 & $-23,447$ & 31 & 0,000 & $\mathrm{H}_{0}$ ditolak \\
\hline & & \multicolumn{4}{c}{ (Neftyan, Suyanto, \& Suyatna, 2018) }
\end{tabular}

Penelitian lain yang dilaksanakan oleh (Nurhidayati, 2016) menunjukkan hasil bahwa terjadi peningkatan hasil belajar peserta didik setelah di terapkannya model CTL dari menggunakan model konvensional, didapatkan nilai $t_{\text {hitung }}$ lebih besar daripada $t_{\text {tabel }}$ yaitu sebesar $34,25>1,67$ dengaan taraf signifikan 0,05 yaitu 2,021 maka $\mathrm{H}_{0}$ ditolak dan $\mathrm{H}_{\mathrm{a}}$ diterima. Sehingga dapat disimpulkan dengan menggunakan model
CTL dapat mempengaruhi peningkatan hasil belajar peserta didik.

Berikut disajikan tabel 4 yang merupakan kajian dari beberapa jurnal yang menggunakan pendekatan pembelajaran CTL terhadap hasil belajar peserta didik:

Tabel 4. Kajian pendekatan pembelajaran CTL terhadap hasil belajar peserta didik

\begin{tabular}{|l|l|l|l|l|}
\hline No & Judul & Penulis & Hasil Jurnal & Kajian Analisis \\
\hline
\end{tabular}




\begin{tabular}{|c|c|c|c|c|}
\hline 1 & $\begin{array}{l}\text { Pengaruh Model } \\
\text { Pembelajaran Contextual } \\
\text { Teaching and Learning } \\
\text { (CTL) Terhadap Hasil } \\
\text { Belajar }\end{array}$ & $\begin{array}{l}\text { Kasmawati } \\
\text { et al. } \\
(2017)\end{array}$ & $\begin{array}{l}\text { Terdapat perbedaan hasil } \\
\text { belajar antara peserta } \\
\text { didik yang diajar } \\
\text { menggunakan } \\
\text { pendekatan CTL ataupun } \\
\text { tidak menggunakan } \\
\text { pendekatan CTL }\end{array}$ & $\begin{array}{l}\text { Bahwa terdapat } \\
\text { perbedaan hasil belajar } \\
\text { peserta didik sehingga } \\
\text { dapat dikatakan bahwa } \\
\text { model pembelajaran CTL } \\
\text { berpengaruh terhadap } \\
\text { hasil belajar }\end{array}$ \\
\hline 2 & $\begin{array}{l}\text { Pengaruh Model Contextual } \\
\text { Teaching and Learning } \\
\text { (CTL) Terhadap Hasil } \\
\text { Belajar Siswa Pada Materi } \\
\text { Fluida Statis di Kelas XI } \\
\text { MAN } 4 \text { Aceh Besar }\end{array}$ & $\begin{array}{l}\text { Gea, F. R. } \\
(2019)\end{array}$ & $\begin{array}{l}\text { Terdapat pengaruh model } \\
\text { pembelajaran CTL } \\
\text { terhadap hasil belajar } \\
\text { siswa pada materi fluida } \\
\text { statis di XI MAN } 4 \text { Aceh } \\
\text { Besar }\end{array}$ & $\begin{array}{l}\text { Peningkatan hasil belajar } \\
\text { peserta didik pada materi } \\
\text { fluida statis di XI MAN } 4 \\
\text { Aceh Besar yaitu karena } \\
\text { adanya pengaruh dari } \\
\text { model pembelajaran CTL }\end{array}$ \\
\hline 3 & $\begin{array}{l}\text { Pembelajaran Fisika } \\
\text { Menggunakan Pendekatan } \\
\text { CTL Berbantuan Media } \\
\text { Video untuk Meningkatkan } \\
\text { Hasil Belajar Siswa }\end{array}$ & $\begin{array}{l}\text { Utami, F. } \\
\text { D. et al } \\
(2018)\end{array}$ & $\begin{array}{l}\text { Pembelajaran fisika } \\
\text { dengan pendekatan CTL } \\
\text { berbantuan video dapat } \\
\text { meningkatkan hasil } \\
\text { belajar peserta didik }\end{array}$ & $\begin{array}{l}\text { Dengan adanya media } \\
\text { berupa video dapat } \\
\text { meningkatkan hasil } \\
\text { belajar peserta didik } \\
\text { dengan menggunakan } \\
\text { pendekatan CTL }\end{array}$ \\
\hline 4 & $\begin{array}{l}\text { Pengaruh Metode } \\
\text { Pembelajaran Contextual } \\
\text { Teaching and Learning } \\
\text { (CTL) dan Pengetahuan } \\
\text { Awal Terhadap Hasil } \\
\text { Belajar Fisika Peserta } \\
\text { Didik Kelas XI MIA MAN } \\
\text { Wajo }\end{array}$ & $\begin{array}{l}\text { Sitti, H et } \\
\text { al (2018) }\end{array}$ & $\begin{array}{l}\text { Terdapat perbedaan hasil } \\
\text { belajar fisika peserta } \\
\text { didik yang diajarkan } \\
\text { dengan metode } \\
\text { pembelajaran CTL dan } \\
\text { metode pembelajaran } \\
\text { langsung pada kelas XI } \\
\text { MIA MAN Wajo }\end{array}$ & $\begin{array}{l}\text { Perbedaan hasil belajar } \\
\text { fisika peserta didik di } \\
\text { kelas XI MIA MAN } \\
\text { Wajo dengan } \\
\text { menggunakan metode } \\
\text { pembelajaran CTL atau } \\
\text { metode pembelajaran } \\
\text { langsung }\end{array}$ \\
\hline 5 & $\begin{array}{l}\text { Penerapan Model } \\
\text { Contextual Teaching and } \\
\text { Learning (CTL) tehadap } \\
\text { Hasil Belajar Fisika pada } \\
\text { Siswa Kelas XI SMA } \\
\text { Handayani Sungguminasa } \\
\text { Kabupaten Gowa }\end{array}$ & $\begin{array}{l}\text { Nurhidayah } \\
\text { et al (2016) }\end{array}$ & $\begin{array}{l}\text { Hasil belajar peserta } \\
\text { didik meningkat dalam } \\
\text { katagori sedang setelah } \\
\text { diterapkannya model } \\
\text { CTL }\end{array}$ & $\begin{array}{l}\text { Terjadi peningkatan hasil } \\
\text { belajar peserta didik } \\
\text { dalam katagori sedang } \\
\text { setelah diterapkan model } \\
\text { CTL }\end{array}$ \\
\hline 6 & $\begin{array}{l}\text { Pengaruh Pendekatan CTL } \\
\text { pada Materi Fluida Statis } \\
\text { Terhadap Hasil Belajar } \\
\text { Fisika Peserta Didik di } \\
\text { SMAN } 1 \text { Mesjid Raya } \\
\text { Aceh Besar }\end{array}$ & $\begin{array}{l}\text { Rahmadani } \\
(2018)\end{array}$ & $\begin{array}{l}\text { Dengan pendekatan CTL } \\
\text { dapat meningkatkan hasil } \\
\text { belajar peserta didik } \\
\text { diperoleh bahwa thitung } \\
>\text { ttabel yaitu sebesar } \\
3.34>2,00\end{array}$ & $\begin{array}{l}\text { Diperoleh bahwa thitung } \\
\text { lebih besar dari ttabel } \\
\text { maka penggunaan } \\
\text { pendekatan CTL dapat } \\
\text { meningkatkan hasil } \\
\text { belajar peserta didik }\end{array}$ \\
\hline 7 & $\begin{array}{l}\text { Penerapan Pendekatan CTL } \\
\text { dalam Pembelajaran Sains } \\
\text { Fisika untuk Meningkatkan } \\
\text { Hasil Belajar Siswa }\end{array}$ & $\begin{array}{l}\text { Handayani, } \\
\text { F. (2017) }\end{array}$ & $\begin{array}{l}\text { Hasil belajar peserta } \\
\text { didik pada penerapan } \\
\text { pendekatan CTL lebih } \\
\text { baik daripada } \\
\text { menggunakan } \\
\text { pembelajaran } \\
\text { konvensional }\end{array}$ & $\begin{array}{l}\text { Meningkatnya hasil } \\
\text { belajar peserta didik } \\
\text { dengan pendekatan CTL } \\
\text { lebih baik daripada } \\
\text { menggunakan } \\
\text { pembelajaran } \\
\text { konvensional }\end{array}$ \\
\hline
\end{tabular}




\begin{tabular}{|c|c|c|c|c|}
\hline 8 & $\begin{array}{l}\text { Pengaruh Pendekatan CTL } \\
\text { melalui Strategi TEQ } \\
\text { terhadap Hasil Belajar } \\
\text { Siswa Kelas X SMAN } 16 \\
\text { Surabaya }\end{array}$ & $\begin{array}{l}\text { Majid, M. } \\
\text { S. et al } \\
(2013)\end{array}$ & $\begin{array}{l}\text { Pendekatan CTL dengan } \\
\text { strategi TEQ } \\
\text { berpengaruh baik } \\
\text { terhadap hasil belajar } \\
\text { dengan thitung } 7,890 \\
\text { lebih besar dai ttabel } \\
\text { sebesar } 1,671\end{array}$ & $\begin{array}{l}\text { Dengan menggunakan } \\
\text { pendekatan CTL dengan } \\
\text { strategi TEQ } \\
\text { berpengaruh pada } \\
\text { peningkatan hasil belajar } \\
\text { dimana thitung lebih } \\
\text { besar daripada ttabel }\end{array}$ \\
\hline 9 & $\begin{array}{l}\text { Pengaruh Penerapan } \\
\text { Pendekatan Contextual } \\
\text { Teaching and Learning } \\
\text { (CTL) terhadap Hasil } \\
\text { Belajar Siswa pada Materi } \\
\text { Perpindahan Panas di Kelas } \\
\text { X SMA Negeri } 14 \\
\text { Surabaya }\end{array}$ & $\begin{array}{l}\text { Jayanti, B. } \\
\text { et al (2013) }\end{array}$ & $\begin{array}{l}\text { Pembelajaran dengan } \\
\text { menggunakan } \\
\text { pendekatan CTL } \\
\text { berpengaruh positif } \\
\text { terhadap hasil belajar } \\
\text { peserta didik }\end{array}$ & $\begin{array}{l}\text { Penggunaan pendekatan } \\
\text { pembelajaran CTL } \\
\text { berpengaruh terhadap } \\
\text { hasil belajar peserta didik }\end{array}$ \\
\hline 10 & $\begin{array}{l}\text { Influence of the Contextual } \\
\text { Teaching and Learning } \\
\text { Model Against Student } \\
\text { Learning Outcome }\end{array}$ & $\begin{array}{l}\text { Juniwati et } \\
\text { al (2020) }\end{array}$ & $\begin{array}{l}\text { Terdapat pengaruh yang } \\
\text { signifikan pada } \\
\text { penggunaan model CTL } \\
\text { terhadap hasil belajar } \\
\text { peserta didik }\end{array}$ & $\begin{array}{l}\text { Bahwa penggunaan } \\
\text { model CTL sangat } \\
\text { berpengaruh terhadap } \\
\text { hasil belajar peserta didik }\end{array}$ \\
\hline 11 & $\begin{array}{l}\text { Effect of Learning Module } \\
\text { with Setting Contextual } \\
\text { Teaching and Learning to } \\
\text { Increase the Understanding } \\
\text { of Concepts }\end{array}$ & $\begin{array}{l}\text { Dewi, P. Y. } \\
\text { et al (2019) }\end{array}$ & $\begin{array}{l}\text { Penggunaan modul } \\
\text { berbasis pembelajaran } \\
\text { CTL lebih tinggi } \\
\text { daripada model } \\
\text { pembelajaran langsung } \\
\text { sehingga dapat } \\
\text { meningkatkan hasil } \\
\text { belajar peserta didik }\end{array}$ & $\begin{array}{l}\text { penggunaan modul } \\
\text { berbasis pembelajaran } \\
\text { CTL lebih cocok } \\
\text { daripada model } \\
\text { pembelajaran langsung } \\
\text { maka terjadi peningkatan } \\
\text { hasil belajar peserta didik }\end{array}$ \\
\hline 12 & $\begin{array}{l}\text { Pengembangan Modul } \\
\text { Fisika Berbasis CTL pada } \\
\text { Fluida Statis dan Fluida } \\
\text { Dinamis untuk } \\
\text { Meningkatkan Prestasi } \\
\text { Fisika SMA Kelas XI IPA }\end{array}$ & $\begin{array}{l}\text { Widarto et } \\
\text { al (2016) }\end{array}$ & $\begin{array}{l}\text { Penggunaan modul } \\
\text { berbasis CTL lebih } \\
\text { efektif untuk } \\
\text { meningkatkan hasil } \\
\text { belajar peserta didik } \\
\text { daripada menggunakan } \\
\text { LKS }\end{array}$ & $\begin{array}{l}\text { Dengan menggunakan } \\
\text { modul berbasis CTL } \\
\text { terjadi peningkatan hasil } \\
\text { belajar peserta didik }\end{array}$ \\
\hline 13 & $\begin{array}{l}\text { Pembelajaran CTL berbasis } \\
\text { Inkuiri untuk Meningkatkan } \\
\text { Pemahaman Konsep dan } \\
\text { Motivasi Belajar Siswa } \\
\text { pada Materi Fluida Statis }\end{array}$ & $\begin{array}{l}\text { Sastriani, } \\
\text { E. et al } \\
(2016)\end{array}$ & $\begin{array}{l}\text { Pembelajaran CTL } \\
\text { berbasis inkuiri dapat } \\
\text { meningkatkan } \\
\text { pemahaman konsep dan } \\
\text { memotivasi belajar } \\
\text { peserta didik sehingga } \\
\text { didapatkan peningkatan } \\
\text { hasil belajar peserta didik }\end{array}$ & $\begin{array}{l}\text { peningkatan pemahaman } \\
\text { konsep dan motivasi } \\
\text { belajar dari penerapan } \\
\text { pembelajaran CTL } \\
\text { berbasis inkuiri sehingga } \\
\text { dapat menigkatkan hasil } \\
\text { belajar peserta didik }\end{array}$ \\
\hline
\end{tabular}

Pada penelitian yang relevan terjadi peningkatan hasil belajar peserta didik setelah diterapkannya pendekatan pembelajaran Contextual Teaching and Learning (CTL). Kondisi tersebut terjadi disebabkan peserta didik dituntut untuk berperan aktif serta melakukan temuannya sendiri sehingga peserta didik sangat berusaha belajar dengan sungguh-sungguh agar hasil yang didapatkan dapat meningkat. 
Berdasarkan kajian data penelitian diatas ada beberapa faktor yang dapat mempengaruhi hasil belajar peserta didik yaitu pendekatan pembelajaran yang digunakan sehingga peserta didik dapat belajar dari sumber lain tidak hanya guru sebagai satu-satunya sumber belajar. Sehingga pemilihan pendekatan pembelajaran mampu mengembangkan pembelajaran agar dapat memenuhi kebutuhan peserta didik.

Pendekatan pembelajaran tersebut harus ada keterkaitan materi yang akan diajarkan dengan kondisi peserta didik. Sehingga dengan pemilihan pendekatan pembelajaran yang tepat maka dapat sesuai dengan hasil yang diharapkan dan sesuai dengan tujuan pembelajaran yang ada. Hal ini sesuai dengan tujuan pendekatan CTL yaitu adanya keterhubungan antara materi yang diajarkan dengan kehidupan sehari-hari.

\section{KESIMPULAN}

Berdasarkan data yang sudah dianalisis didapatkan hasil rata-rata nilai pre-test yaitu sebesar 37. Sedangkan hasil rata-rata nilai posttest sebesar 83 dan rata-rata uji gain ternormalisasi sebesar 0,73. Sehingga didapat bahwa $t_{\text {hitung }}$ lebih besar dari nilai $t_{\text {tabel }}$ maka dapat disimpulkan bahwa dengan menerapkan pendekatan pembelajaran Contextual Teaching and Learning (CTL) terjadi peningkatan hasil belajar peserta didik pada pembelajaran fisika, daripada diterapkannya pendekatan pembelajaran konvensional.

\section{UCAPAN TERIMA KASIH}

Penulis mengucapkan terima kasih pada pihak yang telah membantu, memotivasi, memberi saran dan kritik dalam penyusunan artikel ini, yaitu:

1. Prof. Dr. Munasir, M.Si. selaku Ketua Jurusan Fisika

2. Nadi Suprapto, Ph.D. selaku Ketua Prodi Pendidikan Fisika

3. Orang Tua dan saudara yang telah memberi doa dan dukungan

4. Teman-teman jurusan Fisika, UNESA.

\section{DAFTAR PUSTAKA}

https://ejournal.unib.ac.id/index.php/pendipa
Arends, R. I. (2012). Learning to Teach : Ninth Edition. USA: The McGrawHill Companies.

Dewi, P. Y., \& Primayana , K. H. (2019, Juni). Effect of Learning Module with Setting Contextual Teaching and Learning to Increase the Understanding of Concepts. International Journal of Education and Learning, 1(1), 19-26.

Femi, O. (2011). Teknik Ujian Efektif. Jakarta: PT. Elex Media Komputindo.

Gea, F. R. (2019). Pengaruh Model Contextual Teaching And Learning (CTL) terhadap Hasil Belajar Siswa pada Materi Fluida Statis Di Kelas XI MAN 4 Aceh Besar. Banda Aceh: Universitas Islam Negeri ArRaniry Darussalam.

Handayani, F. (2017, September). Penerapan Pendekatan CTL Dalam Pembelajaran Sains Fisika untuk Meningkatkan Hasil Belajar Siswa. Lembaga Penelitian Universitas Negeri Medan, 193-199.

Jayanti, B., \& Hasanah , R. (2013). Pengaruh Penerapan Pendekatan Contextual Teaching and Learning (CTL) Terhadap Hasil Belajar Siswa pada Materi Perpindahan Panas Di Kelas X SMA Negeri 14 Surabaya. Jurnal Inovasi Pendidikan Fisika, 02(03), 1-5.

Johnson, E. B. (2007). Contextual Teaching and Learning : Menjadikan Kegiatan Belajar Mengajar Mengasyikkan dan Bermakna. Bandung: MLC.

Juniwati, Yusrizal, \& Khaldun, I. (2020). Influence of the Contextual Teaching and Learning Model Against Student Learning Outcome. In Journal of Physics Conference Series, 1460(1), 1-5.

Kasmawati, Latuconsina, N. K., \& Abrar , A. I. (2017, September). Pengaruh Model Pembelajaran Contextual Teaching and Learning (CTL) Terhadap Hasil Belajar. Jurnal Pendidikan Fisika, 5(02), 70-75.

Majid, M. S., \& Suprapto, N. (2013). Pengaruh Pendekatan CTL Melalui Strategi TEQ Terhadap Hasil Belajar Siswa Kelas X SMAN 16 Surabaya. Jurnal Inovasi Pendidikan Fisika, 02(02), 66-69.

Neftyan, C. C., Suyanto, E., \& Suyatna, A. (2018, Juni). The Influence of Learning using Contextual Teaching and Learning Approach to Physics Learning outcomes of High School Students. International Journal 
of Advanced Engineering, Management and Science (IJAEMS), 4(6), 446-450.

Nurhidayah, Yani, A., \& Nurlina. (2018). Penerapan Model Contextual Teaching Learning (CTL) terhadap Hasil Belajar Fisika pada Siswa Kelas XI SMA Handayani Sungguminasa Kabupaten Gowa. Jurnal Pendidikan Fisika Universitas Muhammadiyah Makassar, 161-174.

Nurhidayati, E. (2016). Pengaruh Model Contextual Teaching and Learning (CTL) Terhadap Hasil Belajar Siswa Pada Materi Suhu dan Kalor Kelas X Di SMA Negeri 5 Banda Aceh. Banda Aceh: Universitas Islam Negeri Ar-Raniry Darussalam.

Rahmadani. (2018). Pengaruh Pendekatan Ctl Pada Materi Fluida Statis Terhadap Hasil Belajar Fisika Peserta Didik di SMAN 1 Mesjid Raya Aceh Besar. Banda Aceh: Universitas Islam Negeri Ar-Raniry Darussalam.

Rusman. (2013). Metode-Metode Pembelajaran : Mengembangkan Profesionalisme Guru. Jakarta: PT Raja Grafindo Persada.

Sagala, S. (2011). Konsep dan Makna Pembelajaran. Bandung: Alfabeta.

Sastriani, E., \& Halim, A. (2016). Pembelajaran CTL Berbasis Inkuiri untuk Meningkatkan
Pemahaman Konsep dan Motivasi Belajar Siswa Pada Materi Fluida Statis. Jurnal Pendidikan Sains Indonesia, 04(02), 89-95.

Sitti, H., Kaharuddi, A., \& Muhammad, A. (2018). Pengaruh Metode Pembelajaran Contextual Teaching and Learning (CTL) dan Pengetahuan Awal Terhadap Hasil Belajar Fisika Peserta Didik Kelas Xi Mia Man Wajo. Universitas Negeri Makassar.

Suyadi. (2013). Stategi Pembelajaran Pendidikan Karakter. Bandung: Remaja Rosdakarya.

Thobroni, M., \& Arif, M. (2013). Belajar dan Pembelajaran Pengembangan Wacana dan Praktik Pembelajaran dalam Pembangunan Nasional. Yogyakarta: Ar-Ruzz Media.

Utami, F. D., Sulhadi, \& Sugianto . (2018). Pembelajaran Fisika Menggunakan Pendekatan CTL Berbantuan Media Video untuk Meningkatkan Hasil Belajar Siswa. Unnes Physics Education Journal, 7(02), 94-103.

Widarto, Suparmi, \& Sarwanto. (2016). Pengembangan Modul Fisika Berbasis CTL pada Fluida Statis dan Fluida Dinamis untuk Meningkatkan Prestasi Fisika SMAKelas XI IPA. Jurnal Inkuiri, 5(1), 9-20. 